\title{
Modalidades da decadência: doenças, deformidades e médicos no teatro de Nelson Rodrigues
}

Adriano de Paula RABELO ${ }^{1}$

King's College London

\section{Uma brevíssima trajetória do grotesco}

Um dos aspectos mais marcantes da obra de Nelson Rodrigues é a forma como ele explora o grotesco. Esse termo - de origem italiana com raízes no latim - tem sua primeira formulação na pintura e se referia inicialmente a um estilo ornamental que buscava inspiração em decorações murais da Roma antiga descobertas em ruínas escavadas em torno de 1500, durante o Renascimento. A mais influente dessas descobertas foi a Domus Aurea, palácio não terminado construído por Nero depois do grande incêndio de Roma, em 64 d.C., em cujos corredores os ornamentos exploram as possibilidades estéticas do fantástico e do disforme, fundindo o humano com o animalesco e criando figuras extravagantes, seres imaginários, máscaras que alteram a face pela expressão de emoções muito intensas. Nesses ornamentos, era evidente um apelo à fantasia, ao onírico, a realidades que vão além daquela mais identificada com a vida cotidiana.

No próprio Renascimento, pintores como Leonardo da Vinci e Rafael realizarão fecundas experiências com o grotesco, apesar de serem mais contidos em sua expressão. No entanto, será com os pintores flamengos e alemães que esse estilo deixará de ser mero ornamento para assumir o centro de sua criação. Isso ocorrerá ainda no século XVI com Pieter Brueghel, o Velho, com suas ilustrações dos provérbios; Pieter Brueghel, o Moço, com sua representação de paisagens infernais; Hieronymus Bosch, com obras não convencionais em que homens, animais e demônios se misturam numa ambientação fantástica; Matthias Grünewald, com suas representações do corpo torturado e deformado de Cristo; e Albrecht Dürer, com sua série de gravuras sobre o Apocalipse. Posteriormente, pintores como Goya, Munch e Francis Bacon serão mestres da recriação do grotesco em diferentes épocas.

Em pouco tempo, o termo extrapolou o âmbito da pintura e passou a ser utilizado também nas outras artes. Quanto à literatura, já no próprio século XVI, Montaigne chega a considerar o grotesco como uma espécie de gênero literário que se aproxima da sátira e da

\footnotetext{
1 Adriano de Paula Rabelo é professor da área de Estudos Brasileiros do Departamento de Espanhol, Português e Estudos Latino-Americanos do King's College London. E-mail: aprabelo@hotmail.com.
} 
tragicomédia. Obras-primas da literatura da Antiguidade, como a Teogonia de Hesíodo, a Odisseia de Homero, As metamorfoses de Ovídio e $O$ asno de ouro de Apuleio, já eram pródigas na apresentação de criaturas híbridas, monstruosas ou que se transformavam em seres estranhos. No contexto da Idade Média, autores como Dante, Boccaccio e Rabelais se utilizarão sistematicamente do grotesco para criticar os costumes de seu tempo. E a literatura ocidental posterior terá no grotesco uma de suas vertentes mais criativas, muito especialmente após o advento do Romantismo. Autores tão variados e pertencentes a culturas tão diversas como Jonathan Swift, Ernst Hoffman, Victor Hugo, Edgar Allan Poe, Fiodor Dostoiévski, Lewis Carroll, Émile Zola, Franz Kafka e William Faulkner criarão personagens e situações profundamente marcados pelo grotesco, que se tornara um "estilo genuinamente antiburguês", na definição de Thomas Mann (1933, p. 127).

No teatro, já na tragédia grega, o grotesco se fazia presente, por exemplo, na figura de Édipo cego e amparado por suas filhas Antígona e Ismene até o local de sua morte, tal como representado por Sófocles em Édipo em Colono, ou na presença das Erínias, deidades punidoras dos crimes contra consanguíneos, a perseguir Orestes após este haver matado Clitemnestra, sua própria mãe, e Egisto, amante dela, como vingança pelo fato de o casal haver assassinado Agamenon, seu pai, mito que ganhou forma dramática na trilogia dos átridas, de Ésquilo. Conta-se que, na primeira montagem das três peças, num festival durante o período clássico da Grécia, as Erínias foram representadas como figuras tão terríveis e assustadoras que mulheres grávidas deram à luz em pleno teatro, ao vê-las em cena.

Se a tragédia apresentava o grotesco no plano dos deuses ou ao menos no plano das personalidades míticas da aristocracia, enfatizando os acontecimentos catastróficos, a comédia o apresentava no plano das pessoas comuns, com o fim de enfatizar seus aspectos risíveis. Aristófanes, por exemplo, lança mão do grotesco em suas sátiras políticas para criticar estadistas, filósofos, escritores e outras figuras públicas de Atenas, responsáveis, a seu ver, pela decadência de sua civilização. Já Plauto e Terêncio, em Roma, associarão o grotesco a tipos populares, apontando os defeitos dos avarentos, dos fanfarrões, dos gananciosos e dos ingênuos com o fim de provocar a hilaridade da plateia, que conhecia de perto indivíduos como os seus personagens.

O teatro medieval frequentemente lançava mão do grotesco para atingir a sensibilidade de um público em geral analfabeto que precisava ser educado nas virtudes cristãs por meio de recursos imagísticos. Nos mistérios, milagres, moralidades, dramas litúrgicos e autos sacramentais, gêneros praticados sob patrocínio ou proteção da Igreja, 
muitas vezes o grotesco se mostrava na representação dos demônios e das penas do inferno que aguardavam aqueles que se desviassem dos caminhos da fé e da bondade. Já nos autos profanos, farsas e jograis, gêneros praticados à margem da Igreja, o grotesco se realizava como forma de apontar as falhas de comportamento e os desvios morais de pessoas comuns, na esteira da comédia romana.

No âmbito da Renascença, a commedia dell'arte, que levou ao paroxismo os tipos e as convenções teatrais, explorava permanentemente o grotesco das personagens e das situações. A própria representação de Arlequim, com seus trajes em losangos multicores e sua máscara de nariz enorme e adunco, o distancia das aparências "normais" e de "bom gosto" do século XVI. O grotesco insinuava-se até mesmo nos nomes dos personagenstipo, como Brighella, Pantalone, Pagliaccio, Colombina, Dottore.

Após o Renascimento, quando o termo "grotesco" foi cunhado, grandes dramaturgos explorarão as possibilidades dramáticas dessa categoria estética. Shakespeare, em especial nas grandes tragédias de seu "período sombrio", tais como Hamlet, Rei Lear e Macbeth, utiliza-se extensamente do grotesco para enfatizar os ódios profundos, o desejo de vingança, a intriga e a corrupção que acabam por destruir seus protagonistas. Molière, em suas comédias satíricas, explicita o grotesco dos avarentos, dos falsos devotos, dos burgueses com pretensões a se tornarem sofisticados, dos aristocratas pedantes, dos hipocondríacos ingênuos. Esses defeitos, que não são grotescos dentro de certas medidas, assumem essa qualificação ao ultrapassarem as raias da obsessão e atingirem a dimensão do exagero. No teatro moderno, aquele que se constituiu a partir do final do século XIX, o sueco August Strindberg, precursor do expressionismo e do surrealismo, escreve dramas intensos em que ressalta um mundo deformado pela corrupção, a estupidez e o materialismo vulgar. Já no século XX, o teatro expressionista alemão com frequência utilizará distorções e deformações para representar a interioridade atormentada de seus personagens em obras de dramaturgos como Georg Kaiser, Ernest Toller, Reinhard Sorge e Walter Hasenclever. Mais recentemente, um autor como o suíço Friedrich Dürrenmatt, que sofreu muitas influências do expressionismo alemão, frequentemente explorará o grotesco para ressaltar a banalidade, a insegurança e a violência dos tempos atuais em peças como O casamento do Sr. Mississippi, A visita da velha senhora e Os físicos. E finalmente não se pode deixar de mencionar um dramaturgo como o italiano Luigi Pirandello, que faz uso de toda uma imagística grotesca para demonstrar a futilidade das pessoas na cultura moderna e suas tentativas de encontrar justificativas para seu comportamento, sendo que o grotesco pirandelliano resulta da busca por uma conciliação impossível entre um mundo 
racionalmente ordenado, cuja exterioridade é facilmente reconhecida pela consciência, e o reino do imaginário, que se faz presente através de uma série de construções ficcionais dos indivíduos. Na própria Itália, ainda no tempo de vida de Pirandello - e em decorrência das ideias do dramaturgo siciliano em seu livro O bumorismo -, desenvolveu-se todo um movimento teatral chamado Teatro do Grotesco, que durou de 1916 a 1930. Autores como Rosso di San Secondo e Luigi Antonelli exploraram o grotesco em oposição ao pensamento e a atitude positivista e sua expressão no teatro, o naturalismo. Alguns críticos consideram que Pirandello e o Teatro do Grotesco serão precursores dos mais significativos do chamado Teatro do Absurdo, que marcará profundamente a literatura dramática ocidental e sua concretização cênica em meados do século XX, com grande repercussão até hoje.

\section{A visão de mundo de Nelson Rodrigues}

A estética de Nelson Rodrigues deve muito a dois movimentos literários e suas correspondentes atitudes diante da vida: o Romantismo e o Naturalismo. Já no plano teatral especificamente, o Expressionismo, com o qual ele tomou contato no cinema dos anos 1930, lhe forneceu técnicas e temas que seriam explorados de maneira intensa ao longo de toda a sua carreira como dramaturgo.

Nas obras de Nelson Rodrigues, é como se o romantismo e o naturalismo que constituem a base de seu pensamento e sua sensibilidade estivessem sempre em luta e jamais atingissem uma conciliação. Toda vez que o sublime, o elevado, o ideal, as nobres aspirações estão prestes a se concretizar, invariavelmente o prosaico, o baixo, o vulgar ou o escatológico irrompe, conspurcando a pureza, a inocência e o amor. Assim, em A falecida, Tuninho é acometido por uma dor de barriga logo após anunciar para seus amigos uma bravata heroica de que seria capaz no fim de semana seguinte, quando iria ocorrer no Maracanã a partida final do campeonato carioca de futebol: se tivesse uma grande quantidade de dinheiro, ele apostaria sozinho, contra 200 mil pessoas, na vitória do Vasco da Gama contra o Fluminense. E o prosaísmo escatológico da cena atinge o clímax quando ele chega correndo em casa, mas sua esposa Zulmira está no banheiro, e ele tem de esperar, em pânico, que ela saia. Em $O$ beijo no asfalto, Arandir beija um agonizante que havia acabado de ser atropelado por um lotação no centro do Rio de Janeiro, um ato de pura solidariedade humana que é interpretado por um repórter de polícia que presencia a cena como manifestação de um relacionamento ilícito e anormal entre homens. A boçalidade do 
jornalista contamina toda a cidade durante algum tempo, e Arandir vem a ser destruído pela história folhetinesca que ele cria e explora inescrupulosamente com o fim de vender mais jornal. Já em Bonitinha, mas ordinária, Edgard, atormentado por uma frase do escritor Otto Lara Resende que enfatiza ao lado corrompido e corruptor do ser humano, busca vivenciar em algum lugar um momento de pureza e integridade moral. Ao declarar seu amor por Ritinha num mórbido idílio dentro de um túmulo aberto no decadente Cemitério do Caju, pedindo-lhe um beijo, o rapaz acaba descobrindo que ela atua como prostituta sob a fachada de professora de escola primária, o que só lhe confirma a veracidade da frase de Otto Lara. Para completar, o idílio dos amorosos é interrompido por um coveiro português que aceita uma propina para não incomodá-los, mas recomenda que se apressem, pois um enterro está a caminho. Numa outra passagem da mesma peça, Edgard dá uma carona a Ritinha e leva-a para um lugar isolado na floresta da Tijuca. Ele a beija, e eles ficam muito próximos de consumar no sexo o amor que os unia, mas nesse momento surge Nepomuceno, um leproso que vaga em andrajos pela floresta, e avança sobre o casal, dizendo que era a sua vez de possuir a moça.

Nelson Rodrigues enxergava o ser humano vivendo numa situação de paraíso perdido. Sua tragédia consistiria no fato de, sendo finito e limitado, carregar como uma condenação um permanente anelo pela eternidade, o infinito, a essência das coisas. Apenas o amor eterno, puro e verdadeiro teria a capacidade de redimi-lo dos males que afligem a humanidade. No entanto, seus personagens costumam se mostrar fracos demais para resistir às tentações do mundo, deixando-se levar pela prática do sexo em sua simples materialidade, desvinculado do amor, o que invariavelmente os leva à perdição. Dilacerados pela contradição, ao mesmo tempo em que aspiram a valores bastante elevados, sentem prazer em transgredi-los, recaindo numa espécie de deleite na abjeção, o que invariavelmente resulta numa sensação de culpa e numa necessidade de autopunição. Por fim, o reconhecimento da própria sordidez se realiza, em sua lógica, como uma forma de salvação ou ao menos de preparação para uma vida em sintonia com os valores elevados que cultivam.

Pessimista inveterado, Nelson acreditava que este mundo não é a casa do amor, pois tudo conspira contra ele, que em geral se realiza apenas em momentos intensos e breves de plenitude, raramente com os dois amantes apaixonados e envolvidos de fato no processo amoroso. Viver seria, portanto, recair de sofrimento em sofrimento, de angústia em angústia, e no final geralmente a vida nos logra, destruindo nossas melhores aspirações e não nos concedendo os símbolos de nossa vaidade. Assim, Olegário, em A mulher sem 
pecado, após comprovar a fidelidade imaculada de sua esposa Lídia, recebe a notícia de que ela fugiu com o chofer da família; o negro Ismael, em Anjo negro, em virtude do desejo sexual por sua mulher, a branca Virgínia, deixa morrer a filha que cegou ao nascer e criou para si na crença de que ele fosse o único branco no mundo; Zulmira, em A falecida, que tentou redimir-se da mediocridade de sua vida através de um enterro de luxo, acaba recebendo o enterro mais ordinário, sem sequer a presença do próprio marido, que, ao descobrir ter sido miseravelmente traído, prefere ir ao Maracanã para assistir à final do Campeonato Carioca; o suburbano "Seu" Noronha, em Os sete gatinhos, que prostituíra quatro de suas filhas para que a caçula pudesse ter um casamento dentro dos parâmetros burgueses, vê seu projeto desmoronar quando a adolescente é mandada de volta do colégio interno para casa após não apenas ter perdido a virgindade como engravidado; e o bicheiro Boca de Ouro, na peça homônima, para se redimir do nascimento ordinário numa pia de gafieira, deseja ser enterrado num caixão de ouro, mas não somente é assassinado antes que seu fetiche fique pronto como é enterrado sem sua dentadura de ouro, símbolo de seu poder econômico, pois ela é roubada.

\section{Doenças e deformidades no teatro de Nelson Rodrigues}

O modo como Nelson Rodrigues retrata o grotesco em suas obras se aproxima muito de uma forma naturalista de expressão. Certamente ele foi influenciado por leituras de Émile Zola, um dos escritores mais citados em suas crônicas, mas também não se pode esquecer sua atuação como repórter de polícia no início de sua carreira jornalística, no final da década de 1920, quando a reportagem policial descrevia os crimes de maneira explícita e detalhada, muitas vezes destacando as determinações e as influências do ambiente e de determinados tipos psicológicos no comportamento dos criminosos, em conformidade com teorias científicas em voga na época.

Tal como os escritores naturalistas do século XIX, Nelson Rodrigues lança uma acusação sobre o sistema social, que é visto como doente, pois se sustenta num conjunto de mentiras que impedem o homem de enxergar "a vida como ela é". Para além da superfície das conveniências sociais e da moralidade burguesa, agem forças primitivas e obscuras que, quando encontram vazão, têm um efeito devastador sobre indivíduos e grupos sociais. A exposição dessas forças pelo dramaturgo visa seu reconhecimento, para que elas tenham a possibilidade de serem minimamente controladas por uma ética livre de hipocrisias. 
A personalidade obsessiva e a morbidez do dramaturgo são proverbiais. E uma de suas grandes obsessões é a decadência do homem, que, em suas obras, é simbolizada pelas doenças e deformidades do corpo. Tais doenças e tais deformidades dão um toque de perversidade e degradação moral a quem as possui, à família na qual elas aparecem ou mesmo a toda a sociedade em que se manifestam. Assim, a falsa paralisia de Olegário, em A mulher sem pecado, é a contrapartida física de sua loucura e sua depravação. Em Álbum de família, um ancião que oferece a própria neta a Jonas tem elefantíase. A dona do bordel em Senhora dos afogados, mãe da prostituta assassinada pelo juiz Misael, tem o corpo flácido, pernas grossas (talvez como sintoma da elefantíase) e gazes enroladas nas canelas. De transpiração excessiva e malcheirosa sofrem D. Lígia, a mãe de Alaíde e Lúcia em Vestido de noiva, o negro Ismael em Anjo negro e D. Aracy em Os sete gatinhos. Esta última, chamada pelo apelido de Gorda pelo marido, também sofre com a obesidade, assim como Dr. Werneck, o crápula milionário de Bonitinha, mas ordinária para quem o dinheiro tudo pode comprar. As tias solteironas de Toda nudez será castigada, tal como as primas viúvas em Doroteia, têm morrinha. Dr. Junqueira, o psiquiatra que diagnostica uma suposta loucura de Sônia em $V$ alsa $n^{\circ}$ 6, é manco. Em $A$ serpente, Décio só consegue se realizar sexualmente com a lavadeira de sua família, uma negra gorda e de "ventas triunfais" (RODRIGUES, p. 1120), as mesmas ventas de Hele Nice, criada negra de Salim Simão em Anti-Nelson Rodrigues, que também possui "busto enorme" (Idem, p. 478). De uma feiúra extrema sofrem Tia Rute em Álbum de família, que tem toda uma colônia de espinhas na testa, e as três viúvas de Doroteia, que não possuem nenhuma curva feminina. A loucura acomete toda uma série de personagens de Nelson Rodrigues, como Nonô, em Álbum de família, o filho que, depois de possuir sexualmente a própria mãe, vai viver nos matos que rondam a fazenda de seu pai, rosnando e comendo terra; como Olegário em $A$ mulher sem pecado, que tem um ciúme tão doentio da esposa que chega ao ponto de se fingir de paralítico para testar sua fidelidade; como D. Aninha, na mesma peça, monomaníaca que fica enrolando um paninho o tempo todo em que está em cena; como Gilberto, em Perdoa-me por me traíres, outro ciumento que tem visões dos possíveis amantes de sua mulher e pede que o internem num sanatório para, posteriormente, ao receber alta, lançar-se aos pés dela e lhe pedir perdão por ter sido traído, sendo novamente internado pela família; como D. Berta, em Bonitinha, mas ordinária, que, depois de acusada por um roubo que não havia cometido, passa a andar para trás. A lepra é mencionada em Doroteia e Bonitinha, mas ordinária. Um câncer no seio matou a primeira mulher de Herculano em Toda nudez será castigada, e, na mesma peça, Geni tem obsessão pela doença, já que sua própria mãe havia pronunciado uma maldição de que ela morreria 
desse mal. Em A falecida, essa mesma doença, que resulta na extirpação de um seio da vizinha Glorinha, dá motivo a que Zulmira e Tuninho se divirtam ignominiosamente com seu infortúnio. E não se pode esquecer o aforismo de Otto Lara Resende que, em Bonitinha, mas ordinária, contamina toda uma sociedade, dando carta branca a todos para agirem como canalhas e justificando sua maldade: "O mineiro só é solidário no câncer". Ainda em $A$ falecida, Zulmira morre com sintomas evidentes de uma tuberculose mal diagnosticada e mal tratada. A cegueira atinge Ana Maria e Elias, em Anjo negro, que perderam a visão devido a intervenções criminosas do protagonista Ismael. E essa deficiência é utilizada para uma comparação poética numa fala Sônia em $V$ alsa $n^{\circ}$ 6: "Meus gritos batiam nas paredes, nos móveis, como pássaros cegos" (Idem, p. 400).

Além desses males, é comum que Nelson Rodrigues mencione, em seus contos, crônicas e romances, outros como as rugas, o mau hálito, o odor das axilas, os vermes, as varizes, as acnes, a coriza.

Curiosamente, até mesmo a beleza, quando excessiva, é vista pelo dramaturgo como fonte de desgraças e perdições, pois mobiliza os sedutores e dispara o desejo sexual, invariavelmente desencadeando uma série de infortúnios. Por ser muito bonita, D. Senhorinha, em Álbum de família, é desejada pelos próprios filhos, o que resulta na loucura de um e no suicídio de outro; e Doroteia, na peça homônima, tem as feições agradáveis, o hálito bom, os seios perfeitos e as costas sem espinhas amaldiçoados pelas primas, só se redimindo e sendo aceita ao adquirir as chagas leprosas que destruirão sua bela aparência e farão com que ela deixe de ser perseguida pelo jarro, símbolo do desejo sexual, podendo enfim apodrecer juntamente com D. Flávia, a última remanescente de uma linhagem de mulheres recalcadas, num triunfo da pulsão de morte.

Uma leitura extensiva da obra de Nelson Rodrigues deixa claro que, entre todos esses males, aqueles pelos quais ele tem verdadeira fixação, mencionando-os recorrentemente, são a cegueira, o câncer, a lepra e a tuberculose, não por acaso deficiências e enfermidades gravíssimas que não somente provocam um sofrimento atroz, mas também possuem algo de espetacular e algo que promove, por si só, uma forte individualização do deficiente ou doente no convívio social, tema esse muito caro ao escritor.

Se as doenças e deformidades enfatizam a decadência do homem contemporâneo na obra de dramaturgo, como elas são apresentadas em seu paroxismo, frequentemente adentram pelo campo do absurdo e ajudam a compor o clima das situações-limite em que seus personagens se movimentam. E o grotesco, tal como expresso por ele, parece dever 
muito ao Naturalismo, já que, não resistindo às tentações e praticando o sexo pelo sexo, desvinculado do amor, seus personagens regridem imediatamente à condição de mera animalidade. Além disso, ao dar vazão a seus instintos, eles perdem o controle de si mesmos e permitem a irrupção de forças incontroláveis que habitam seu inconsciente, o que aproxima seus infortúnios de uma espécie de determinismo.

Os aspectos grotescos no teatro de Nelson Rodrigues chocam e auxiliam no desencadeamento de processo trágico, mas também, pelo exagero, com frequência adentram pelo risível. Henri Bergson (2001), em O riso, defende que a comicidade só se torna possível quando se ultrapassam certas medidas, quando o excesso faz com que se fuja à chamada "normalidade". Isso provoca uma imediata não identificação, e o riso começa apenas quando termina a comoção. Nas peças do dramaturgo, isso acontece muitas vezes. Por exemplo, o estratagema de Olegário, que se finge de paralítico para testar a fidelidade da esposa em $A$ mulher sem pecado, é algo tão desmedido que se torna cômico, o que não aconteceria se ele fosse realmente aleijado. A atitude de Gilberto em Perdoa-me por me traíres, ao se lançar aos pés da esposa adúltera e lhe pedir perdão por traí-lo, é tão fora de qualquer comportamento convencional ou esperado que provoca o riso na plateia. Em Bonitinha, mas ordinária, a gordura de Werneck, que se sente um "Nero de Cecil B. de Mille" (Idem, p. 1017) ao receber massagem, torna-se cômica ao remeter a sua acumulação capitalista desenfreada e sua falta de escrúpulos no uso do dinheiro. E a frase terrível de Otto Lara Resende, que é o leitmotiv da peça, também se torna risível ao ser repetida à exaustão.

Portanto, se as doenças e deformidades que abundam no teatro de Nelson Rodrigues por um lado são a contrapartida física das doenças e deformidades morais de um indivíduo, de um grupo social ou mesmo de toda uma sociedade, realizando-se como a expressão mais enfática de sua visão do ser humano em decadência, por outro elas se refletem nos aspectos formais de suas peças, contribuindo para os efeitos do encadeamento trágico que quase sempre resulta na destruição de seus protagonistas, mas também temperando o enredo com uma comicidade que lança mão do humor negro, da sátira e do sarcasmo. Se há uma prevalência da forma trágica e se os desfechos de suas obras tendem à gravidade, nelas o dramaturgo invariavelmente mistura muitos elementos da comédia, da farsa e do melodrama, mostrando que a profundidade dramática e a tensão trágica não são incompatíveis com o riso.

\section{Os médicos no teatro de Nelson Rodrigues}


Numa dramaturgia tão marcada pela presença de variadas doenças e deformidades, criada por um autor que cultivava tamanha obsessão por elas, aqueles que tratam desses males necessariamente se fariam presentes e desempenhariam um papel de destaque. A forma como os médicos são apresentados no teatro de Nelson Rodrigues tem pontos em comum com o modo como a comédia e a farsa tradicionalmente lidam com eles. Ridicularizar os médicos é um verdadeiro topos dos gêneros cômicos. Já Aristófanes, no século V a.C., em duas de suas peças, As vespas e Arcânio, menciona certo Dr. Pitalo, uma espécie de médico público de Atenas especializado no tratamento beberrões e irresponsáveis de toda sorte.

Num estudo sobre o teatro da Antiguidade, Francis Cornford registra que o tópico da sátira aos médicos se formou entre os comediógrafos gregos e latinos, tendo constituído uma longa história nos palcos da Grécia e de Roma:

A figura do médico pode ser acompanhada nas obras de vários poetas da Comédia Intermediária até o Doutor ('Iajœós) de Filêmon, o Parasitus medicus de Plauto e um fragmento de Dífilo, em que um médico promete ao paciente uma cura rápida... ou a morte. Pode-se vê-lo em seu mais elevado desenvolvimento em Os Menecmos, de Plauto, quando um médico chega à cidade após uma demora bem planejada, faz uma série de perguntas a seu guia, utilizando muitos termos técnicos, e tem grande confiança em que salvará seu paciente antes de encontrá-lo, mas, quando está diante dele, declara que aquele é um caso difícil, faz perguntas absurdas com vistas ao diagnóstico, responde-as com solenidade, fala demais e, por fim, não faz nada. E nem assim deixa de manifestar nenhum dos sintomas da alozoneia. ${ }^{2}$ (CORNFORD, 2011, p. 177)

O teatro cômico do Renascimento, que retoma muitos aspectos do teatro antigo, dá prosseguimento à tendência de ridicularizar os médicos. Em $A$ mandrágora, Nicolau Maquiavel coloca em cena um jovem impostor que finge ser médico para conquistar uma mulher casada que não podia ter filhos, receitando-lhe uma planta afrodisíaca e vindo a tornar-se o seu amante.

Um dos personagens fixos da commedia dell'arte era Graziano, às vezes também chamado Balanzone, médico pedante e presunçoso que falava em dialeto bolonhês intercalado por expressões latinas de almanaque. Baixo e gordo, sempre carregava um livro e ostentava uma falsa erudição, sendo sempre enganado pelos outros por ser, em realidade, um ingênuo. Marido ciumento, sua esposa the era geralmente infiel.

Shakespeare, em $A$ comédia dos erros, uma recriação de Os menecmos, de Plauto, coloca em cena um médico charlatão chamado Dr. Pinch ${ }^{3}$, que cuida do protagonista Antífolo de

\footnotetext{
${ }^{2}$ Orgulho jactancioso.

3 A palavra pinch pode ser traduzida por "beliscão" ou "aperto"; num outro sentido, por "roubo". 
Éfeso, que, após uma sucessão de confusões devido à semelhança com seu irmão gêmeo Antífolo de Siracusa, acredita que a cidade aonde havia chegado é enfeitiçada. Pinch sugere que Antífolo e seu escravo Drômio sejam amarrados e que se deitem numa sala escura para que o "demônio" seja exorcizado de seus corpos.

Certamente o comediógrafo que mais ridicularizou esses profissionais foi Molière. O dramaturgo francês, que era um homem de saúde frágil, teve de ter uma longa e frequente convivência com os médicos ao longo de sua vida, tornando-se um fino observador de seus cacoetes, de suas vaidades e da incompetência de alguns deles. Às vezes os médicos do teatro de Molière se misturam à figura do erudito - ou do pseudo erudito -, outro de seus alvos favoritos. Em peças como $O$ médico voador, $O$ doutor apaixonado, $O$ casamento forçado, D. Juan, O amor médico, Médico à força e $O$ doente imaginário, ele coloca em cena médicos que se caracterizam pela pedanteria, a incapacidade, o uso do jargão incompreensível para os não iniciados na medicina, a ingenuidade. Algumas vezes o simples fato de alguém vestir uma roupa branca de médico é suficiente para que seus "diagnósticos" se tornem plausíveis. Em várias de suas comédias, há um personagem chamado Sganarelle, que numa peça é um lacaio, noutra um lenhador, noutra um solteirão que resolve se casar e noutra um pai egoísta e cego à vida amorosa da filha. Em $O$ médico voador e Médico à força, por exemplo, esse personagem arma e conduz uma trama bastante intrincada ao fingir-se de médico para ajudar uma mocinha que seria obrigada pelo pai a se casar com um pretendente imposto, fazendo com que, no fim, após muita confusão, ela se una ao homem que ama verdadeiramente.

O próprio teatro brasileiro tem a sua tradição de tratar os médicos de forma pouco lisonjeira. Num tempo em que defensores das diversas correntes da medicina travavam acirrado debate no Brasil, Martins Pena escreveu Os três médicos, satirizando o radicalismo das teorias científicas do século XIX e a presunção de muitos profissionais da medicina. Em sua peça, Marcos, um pai de família, está seriamente enfermo. Para se tratar, ele chama Dr. Cautério, um alopata; seu filho Miguel chama Dr. Miléssimo, um homeopata; e seu amigo Lino das Mercês chama Dr. Aquoso, um hidropata. Os três médicos passam a agir simultaneamente, mas cada um defende a sua especialidade, desprezando a dos outros, nunca chegando a um acordo. Suas divergências vão num crescendo até que, após uma discussão regada a insultos e descomposturas, os três entram em luta corporal. No fim, as três especialidades se revelam inúteis, pois se descobre que o sofrimento de Marcos tinha, em realidade, uma causa moral. 
Já Machado de Assis, em Não consultes médico, coloca em cena D. Leocádia, médica das enfermidades morais e sentimentais. Por sua intervenção, curaram-se a solidão de Magalhães e a hipocondria de D. Adelaide através de seu casamento, e eles vieram a ter uma filha, Carlota. Esta passa por uma fase de desilusão amorosa. A família, porém, costuma ser visitada pelo excêntrico e deprimido Dr. Cavalcanti, amigo de Magalhães, que ficou tão frustrado após o fim de um romance que desistiu do amor e pensa em tornar-se monge. Quando D. Leocádia descobre que os dois jovens são vítimas de amores fracassados, resolve intervir pela "cura" de seus males, fazendo com que simplesmente conversem a sós e compartilhem seu desapontamento. Como era de se esperar, durante as confissões mútuas os dois se apaixonam. E a peça termina com Cavalcanti pedindo a mão de Carlota em casamento. Confirma-se o provérbio grego que é o mote do texto: "Não consultes médico; consulta alguém que tenha estado doente".

Logo depois de a Escola de Medicina do Rio de Janeiro diplomar a primeira médica e a primeira farmacêutica brasileiras, acontecimentos que geraram muita polêmica na época, França Júnior escreveu As doutoras, texto de 1889. Na peça, Luísa forma-se em Medicina e se casa com Pereira, também médico recém-formado. No entanto, a mãe da moça questiona a relação sentimental do casal, pois eles passam o tempo todo discutindo teorias médicas. Além disso, passam a disputar pacientes. Quando Luísa, especialista em doenças de mulheres e crianças, atende um homem em seu consultório, o marido descobre, e eles discutem acerbamente, falando em divórcio. No entanto, pouco depois revela-se que ela está grávida, e a crise é superada. A solução para o problema familiar é encontrada à maneira da época: Luísa abandona a clínica para assumir por completo o papel de dona de casa e dedicar-se a Luisinho, o filho.

Os médicos de Nelson Rodrigues invariavelmente são eles próprios figuras grotescas e com frequência sobrecarregadas de ridículo. Portanto, não provocam nenhuma identificação, mas antes indignação, algumas vezes o riso. Tal como Molière, Nelson também foi uma pessoa de saúde fragilizada, tendo sido obrigado a ter uma convivência contínua com os profissionais da medicina desde a juventude, o que lhe proporcionou um conhecimento profundo de seus trejeitos e manias. O ridículo dos médicos do dramaturgo já começa por seus nomes: Dr. Sanatório, Dr. Lambreta, Dr. Borborema, Dr. Bordalo. Nelson Rodrigues tem obsessão por algumas especialidades da medicina, como a ginecologia e a pediatria, mas outras também aparecem em sua obra, como a otorrinolaringologia e a pneumologia. Clínicos gerais e cirurgiões também se fazem presentes. E psicanalistas, psiquiatras e dentistas são tratados da mesma forma, também 
fazendo parte da categoria dos médicos. Esses profissionais representam o oposto da filosofia de base romântica e cristã professada tão radicalmente pelo escritor. Sempre que aparecem em seu teatro, os médicos encarnam a falta de reverência pela vida eterna, o materialismo e o amoralismo, pois manipulam o corpo humano em sua simples materialidade e, quanto tratam da mente, revolvem trevas interiores que convém não provocar, além de encararem o sexo de modo apenas técnico, cegos para a necessidade do amor para legitimá-lo e torná-lo pleno. Essa representação que o dramaturgo faz dos médicos pode ser interpretada como expressão de sua tendência para o ataque a toda postura desumana e desumanizadora. No conjunto de sua obra, essa tendência também se realiza por meio dos ataques aos regimes totalitários, aos juízos massificados e às ideologias que desconsideram o indivíduo.

Das 17 peças de Nelson Rodrigues, nove apresentam médicos como personagens e numa um médico é evocado a propósito da reconstituição de virgindades perdidas.

Em Vestido de noiva, após ser atropelada, Alaíde é conduzida para o hospital, passando os últimos momentos de sua vida sob os cuidados de médicos completamente insensíveis à sua tragédia. Questionado por Pedro, o noivo da moça, sobre se ela estaria sofrendo, um médico de plantão dá a seguinte resposta: "Não. Nada. Chegou em estado de choque. Nem vai sofrer nada. (...) E isso para o acidentado é uma felicidade. Uma grande coisa. A pessoa não sente nada - nada.” (RODRIGUES, 2003, p. 380). Ao longo da peça, alguns flashes no plano da realidade mostram os médicos trabalhando friamente sobre o corpo de Alaíde na mesa de operação, destrinçando-o como se fosse uma coisa qualquer e fazendo comentários impertinentes sobre a beleza de suas formas e o estado civil da moça. Neste caso, em vez de provocar hilaridade, o grotesco dos médicos desperta a revolta do espectador.

Repulsa é também o sentimento provocado pelo protagonista de Anjo negro, Ismael, um negro que "estudava muito para ser mais que os brancos, quis ser médico - só por orgulho, tudo orgulho" (Idem, p. 585), conforme Elias, seu irmão. Não se vê Ismael praticando sua profissão, mas há indicações de que ele é bom em seu métier. A indignação que provoca resulta de seu caráter racista e suas atitudes de extrema maldade por causa do ódio a sua cor, o que o leva a cegar o irmão e a filha, criando esta na ilusão de que só existiam negros no mundo e que ele era o único branco. No final, por desejo sexual desenfreado por sua mulher, a branca Virgínia, o casal mata a adolescente Ana Maria, a única filha que havia se salvado da loucura assassina de seus genitores. E o ciclo de conceber e dar à luz filhos malditos se renova. 
A partir de $\operatorname{Valsa} n^{\circ} 6$, algumas vezes os médicos costumam aparecer, no teatro de Nelson Rodrigues, num registro mais próximo do cômico, apesar de essencialmente eles continuarem provocando indignação por sua desumanidade. Como se viu, o psiquiatra Dr. Junqueira que considera a menina Sônia como uma desequilibrada mental após ela ter alucinações, é um velho manco, possui uma aparência medonha e tem uma fixação um tanto erótica por ver as amígdalas da garota. Sua paciente se lembra de que uma vez, após ela ter tido uma de suas crises alucinatórias, ele veio acudi-la vestido num pijama e numa capa de borracha. Em sua memória fragilizada, Sônia imagina-o tendo apenas pacientes femininas e pagando passagem no bonde para moças que ele nunca viu. E seu diagnóstico do mal que afetava a menina é apenas o de que ela estava se transformado em mulher após ter sido deflorada pelo primo, Paulo.

Em $A$ falecida, a protagonista Zulmira, com evidentes sintomas de uma tuberculose crônica, vai se consultar com o um velho pneumologista, o Dr. Borborema, que a recebe de óculos e avental. Mesmo com a paciente dizendo-lhe que anda "sentindo o diabo" e que naquele dia mesmo "está com um gosto horrível de sangue na boca" (Idem, p. 755), o médico não detecta nada de anormal em seus pulmões, concluindo que tudo está bem e finalizando a consulta com uma menção ao clássico futebolístico do domingo seguinte. Por fim, lamentando sua condição econômica, que não lhe permite consultar-se com um profissional de melhor qualidade, Zulmira faz a seguinte avaliação do Dr. Borborema: "um médico do tempo de D. João Charuto, completamente gagá! Ainda por cima, fiquei, sem o mínimo exagero, umas 37 horas, na sala, esperando, e com esse calor!” (Idem, ibidem).

Em Perdoa-me por me traíres, o grotesco recai sobre um ginecologista que, na realidade, é um "fazedor de anjos". Na sala de espera de seu consultório estão "sentadas mocinhas escuras e apavoradas, que parecem criadas domésticas" (Idem, p. 794). Numa cena marcante da peça, a adolescente Nair, que se iniciara na prostituição ao lado da amiga Glorinha, procura o médico para fazer um aborto. Este, quando surge em cena, vem chupando tangerina e jogando fora as sementes. A cirurgia abortiva é feita sem anestesia, e Nair sofre uma grave hemorragia, vindo a morrer na mesa do ginecologista. Diante da paciente agonizante, ele se preocupa apenas com sua reputação: "Imagine! eu me sujar por causa de uma prostitutazinha! (Suplicante.) Se houver escândalo, com que cara vou aparecer perante a besta do meu sogro, que é metido a Caxias?” (Idem, p. 796). Isso após insinuar que tem um caso com a enfermeira que o auxilia nos procedimentos abortivos. Até que, esgotados todos os seus recursos, ele grita em desespero para que a enfermeira reze, caindo ele mesmo em prantos diante da garota, que se esvai em sangue. 
$\mathrm{Na}$ "farsa irresponsável" Viúva, porém honesta, os médicos são tratados de forma escrachada, predominando sua representação pelo viés do ridículo. A intriga parte da obsessão de Ivonete pela viuvez, pois a única coisa que ela faz é velar Dorothy Dalton, o marido morto, recusando-se inclusive a sentar-se, pois isso seria uma afronta à memória do defunto. Seu pai, Dr. J.B. de Albuquerque Guimarães, diretor do jornal “A Marreta”, um dos mais influentes do país, tenta resolver a situação, para que sua filha única, de apenas 15 anos, possa se casar novamente e lhe proporcionar os netos que darão continuidade a seus negócios. Por isso, ele contrata a ex-prostituta Madame Cricri, o psicanalista Dr. Lupicínio e o otorrinolaringologista Dr. Sanatório para tentar trazê-la de volta à vida "normal", incutindo-lhe o desejo de se casar de novo. Dorothy Dalton, que morreu ridiculamente atropelado por uma carrocinha de Chicabon, era um homossexual e ex-fugitivo da FEBEM, além de crítico de teatro da nova geração, quando foi escolhido por Ivonete na redação do jornal de seu pai, para dar justificativa a uma gravidez indesejada que havia sido descoberta pelo ginecologista da família, Dr. Lambreta, velho esclerosado e insano. Mais tarde se revelará que a gravidez da garota era falsa, produto da mente degenerada do médico. E como nem a prostituta, nem o psicanalista, nem o otorrinolaringologista conseguem solucionar o caso, o último recurso é ressuscitar o Dorothy Dalton, para que Ivonete deixe de ser viúva. O escolhido para essa missão é Diabo da Fonseca, que, por meio de uma sessão espírita, reaviva o ex-marido de Ivonete, livrando-a de uma viuvez tão inconveniente. Como prêmio, o demônio se torna o segundo marido da menina.

Em Os sete gatinhos, o clínico familiar Dr. Bordalo vai até a casa de "Seu" Noronha para examinar sua filha caçula, a adolescente Silene. Na ocasião, o médico constata que ela está grávida, o que destruirá toda a esperança de purificação e redenção de uma família corroída pela hediondez. Ao revelar o estado da menina para "Seu” Noronha, Dr. Bordalo se mostra compreensivo e pede que ele não faça um escarcéu, pois, a seu ver, "a virgindade é apenas uma peliculazinha" (Idem, p. 856). A desilusão de Noronha faz com que ele resolva fazer sua família chafurdar inteiramente na lama da abjeção, criando na própria casa um bordel de filhas. Em seguida propõe a Dr. Bordalo que seja o primeiro cliente de Silene. O médico reluta, mas acaba aceitando fazer um programa com a menina, pensando em sua própria filha da mesma idade. Assumindo plenamente a sua canalhice, Dr. Bordalo vai cambaleando para o quarto com Silene, mas não sem antes implorar a Aurora, irmã da garota, que lhe cuspa na cara.

Em Boca de Ouro e Bonitinha, mas ordinária, a figura do médico é apresentada muito brevemente ou apenas mencionada, mas segue o paradigma da dramaturgia de Nelson. A 
primeira peça inicia-se com o personagem-título num consultório, subornando um dentista para que lhe arranque todos os dentes, que são perfeitos, e os substitua por uma dentadura de ouro. O odontólogo reluta, mas se deixa comprar pelas cédulas que Boca de Ouro lhe coloca nos bolsos ou deixa cair pelo chão, realizando um serviço que rompe radicalmente com a ética de sua profissão. Já na segunda peça, o milionário Heitor Werneck, após patrocinar uma orgia em que duas adolescentes suburbanas virgens são estupradas para deleite de um grupo de grã-finos, seus amigos, menciona um médico cirurgião de suas relações, especialista em restaurar virgindades. É só pagar por isso, e, afinal, dinheiro não lhe falta. Em ambos os casos está presente o poder corruptor do dinheiro, que, numa sociedade degenerada, tudo pode comprar.

Por fim, em Toda nudez será castigada também há a presença de um médico de família, que também teria tido um caso com a enfermeira, vindo a se amigar com ela. Sem possuir aspectos grotescos muito carregados, sua deformidade está na falta de espanto diante dos acontecimentos mais traumáticos, em seu materialismo rasteiro e na negação da transcendência, o que é algo muito grave no mundo de Nelson Rodrigues. Ao ser questionado pelo viúvo Herculano sobre se acredita em milagre, o clínico afirma acreditar apenas no homem, o que faz com que o dramaturgo coloque na boca de seu interlocutor uma de suas frases típicas: "Se tirarem do homem a vida eterna, ele cai de quatro, imediatamente" (Idem, p. 1100). No mesmo diálogo, é próprio o médico quem pronuncia outro pensamento típico: "Não há, nunca houve o canalha integral, o pulha absoluto. O sujeito mais degradado tem a salvação em si, lá dentro" (Idem, p. 1101). Como outros médicos na obra de Nelson, este lida com o homem em sua dimensão puramente biológica e animal, o que para o escritor entra no campo das posturas desumanizadoras que ele tanto abominava.

Se na tradição da comédia os médicos tendem mais para o ridículo, sendo o grotesco um acessório para enfatizar o escárnio e a zombaria de que são merecedores, no teatro de Nelson Rodrigues as coisas se invertem, já que seus médicos são figuras essencialmente grotescas, marcadas pelo disforme, a extravagância e o bizarro. Neles o ridículo é que auxilia na construção de caracteres mais repulsivos que risíveis, apesar de esta dimensão também se fazer presente.

Se as doenças e deformidades são expressões visíveis da degradação moral de uma pessoa, de uma família ou mesmo de toda a sociedade, os médicos do dramaturgo brasileiro não estão imunes a essa degradação, mas participam dela e a intensificam. Como os outros personagens, eles também são "humanos, demasiado humanos". 


\section{Razão e finalidade do grotesco em Nelson Rodrigues}

A que serve a exploração das potencialidades do grotesco no teatro de Nelson Rodrigues? A resposta talvez possa ser encontrada em alguns de seus escritos, nos quais ele esboça uma espécie de teoria do teatro. Num texto escrito para a apresentação de Perdoa-me por me traíres, para confrontar as costumeiras acusações que pesavam sobre suas peças, ele se antecipa aos críticos:

Morbidez? Sensacionalismo? Não. E explico: a ficção, para ser purificadora, precisa ser atroz. O personagem é vil, para que não o sejamos. Ele realiza a miséria inconfessa de cada um de nós. A partir do momento em que Ana Karenina, ou Bovary, trai, muitas senhoras da vida real deixarão de fazê-lo. No Crime e Castigo, Raskolnikov mata uma velha e, no mesmo instante, o ódio social que fermenta em nós estará diminuído, aplacado. Ele matou por todos. E, no teatro, que é mais plástico, direto, e de um impacto tão mais puro, esse fenômeno de transferência torna-se mais válido. Para salvar a plateia, é preciso encher o palco de assassinos, de adúlteros, de insanos e, em suma, de uma rajada de monstros. São os nossos monstros, dos quais eventualmente nos libertamos, para depois recriá-los. (RODRIGUES apud CASTRO, 2001, p. 273)

Portanto, o dramaturgo recorrentemente apresentava as doenças e deformidades de indivíduos, de grupos sociais ou mesmo de toda uma sociedade - explorando o mórbido, o bizarro e às vezes até o macabro - como uma forma de fazer com que uma audiência que se acreditava saudável se olhasse no espelho e se reconhecesse como também deformada e doente. Além disso, seu teatro teria uma função catártica, provocando um efeito psicológico liberador, pois essa mesma audiência viveria vicariamente sua "miséria inconfessa" por meio das monstruosidades que assistem no palco, deixando de dar vazão a essa miséria no âmbito da vida real. Em suas crônicas, o escritor muitas vezes rebatia na tecla da necessidade de olharmos para o lado escuro de nós mesmos, de enfrentarmos a angústia, a solidão, a perda e até de sermos francamente neuróticos, pois este seria uma espécie de caminho para a salvação por vias tortas que constituiria a única possibilidade de redenção para aqueles que vieram a este mundo sem terem sido tocados pelo dom da santidade.

\section{BIBLIOGAFIA CITADA:}

BERGSON, Henri. O riso: ensaio sobre a significação da comicidade. São Paulo, Martins Fontes, 2001.

CASTRO, Ruy. O anjo pornográfico: a vida de Nelson Rodrigues. São Paulo, Companhia das Letras, 2001. 
ECO, Umberto. História da feiúra. Rio de Janeiro, Record, 2007.

FANTHAN, Elaine. Roman readings: roman response to greek literature from Plautus to Statius and Quintilian. Berlin, De Guyter, 2011.

HARPHAM, Geoffrey Galt. On the grotesque: strategies of contradiction in art and literature. Aurora, The Davies Group, 2007.

JEHA, Julio (Org.). Monstros e monstruosidades na literatura. Belo Horizonte, Editora da UFMG, 2007. KAYSER, Wolfgang. O grotesco. São Paulo, Perspectiva, 2009.

MAGALDI, Sábato. Teatro da obsessão: Nelson Rodrigues. São Paulo, Global, 2004.

MANN, Thomas. Past masters and other papers. New York, Alfred A. Knopf, 1933.

MOLIĖRE. Théatre complet. Paris, Bibliothèque des Introuvables, 2008.

RODRIGUES, Nelson. Teatro completo. Rio de Janeiro, Nova Aguilar, 2003.

CORNFORD, Francis MacDonald. "The stock masks in the old comedy". In: The origin of attic comedy. Cambridge, Cambridge University Press, 2011. pp. 154-189.

Abstract: This article approaches the way through which Nelson Rodrigues depicts disease, deformity and doctors in his theatrical works. Starting from a brief trajectory of the grotesque as a concept and presenting the playwright's world vision, this text analyses how illness and deformation are shown in his plays, as well as the professionals who treat them. Finally, it reflects on the reasons and purposes of grotesque in Rodrigues' works.

Keywords: Nelson Rodrigues; grotesque; humor; modern theatre. 